\title{
Kepentingan Nasional dan Diplomasi ala Indonesia dalam Penyelesaian Konflik Etnis Rohingya di Myanmar
}

\author{
Glen Matthew \\ Universitas Padjadjaran
}

\begin{abstract}
ABSTRAK
Konflik Etnis Rohingya di Myanmar telah lama menjadi isu yang krusial di tengah-tengah perhelatan global, bahkan sejak era penjajahan Inggris. Melihat durasi yang cukup lama tersebut, maka pengambilan langkahlangkah konkret sangat dibutuhkan dalam menyelesaikan perselisihan antara kaum Muslim Rohingya dan masyarakat Rakhine yang beragama Buddha. Artikel ini lantas bertujuan untuk melihat kepentingan nasional Indonesia dan pendekatan yang dilakukan Indonesia dalam berdiplomasi sebagai negara dengan jumlah penduduk Muslim terbesar di dunia sekaligus sebagai sesama negara ASEAN, dalam proses penyelesaian konflik Etnis Rohingnya. Penulis mengamati kepentingan nasional Indonesia dalam isu ini dengan menggunakan paradigma realisme, salah satu teori dalam studi Hubungan Internasional, yang berkutat di sekitar diskursus kekuasaan dan dominasi. Penelitian dilakukan dengan menggunakan metode kualitatif melaluistudi literatur. Hasil penelitian penulis menunjukkan bahwa di dalam mencapai kepentingan nasional, Indonesia telah menggunakan pendekatan diplomasi ala Indonesia yang terangkum dalam kebijakan politik luar negeri "bebas-aktif".
\end{abstract}

Kata-kata Kunci: Konflik, Rohingya, Indonesia, Myanmar, Kepentingan Nasional, Diplomasi, Realisme

Rohingya ethnic conflict in Myanmar has been a crucial issue in the midst of global affairs. Having been endured since the British colonial era, concrete actions are urgently needed in resolving the tensions involving both Rohingya Muslims and Buddhist Rakhine. With its escalation turned onto sectarian conflicts, conflict resolution is getting more imperative to be done. This article is aimed to see the national interest of Indonesia and Its diplomatic approach as a country with the largest Muslim population in the world, as well as fellow ASEAN countries, in the process of ending Rohingya ethnic conflict. The author will examine this further by using frameworks offered by the realist point of view, one of the prominent theoretical approach in the study of International Relations, centered around the discourse of power and domination. The research will be conducted in a qualitative manner by doing a literature study. The results of research from various sources, show that in achieving national interests, Indonesia has pursued diplomatic approaches as in accordance with the "free-and-active" foreign policy principles.

Keywords: Conflict, Rohingya, Indonesia, Myanmar, National Interest, Diplomacy, Realism 
Konflik etnis Rohingya telah lama membara di Myanmar. Sebagai konsekuensi dari fenomena ini, ribuan orang Rohingya melarikan diri dari tempat kediaman mereka. Banyak dari rumah-rumah dan desa-desa yang dahulu didominasi oleh kelompok etnis tersebut yang kini hancur. Krisis kemanusiaan pun semakin ter-erupsi di kawasan ini. Bahkan, Jati (2018) menuturkan bahwa, krisis yang melanda etnis Rohingya ini dapat dikatakan sebagai krisis kemanusiaan terburuk semenjak krisis di Vietnam yang terjadi di era 1970an lalu. Tragedi ini telah mendapat perhatian dunia lewat berbagai tulisan yang ada di dalam berbagai artikel sejak tahun 1990an. Tercatat bahwa orang-orang Rohingya kerap kali mendapat tekanan dari pemerintah mereka sendiri. Mengingat durasi dan intensitas konflik ini yang semakin meninggi, serta korban yang semakin bertambah, lantas menjadi imperatif untuk segera menyelesaikan konflik ini.

Pelarian merupakan jalan terakhir yang dilakukan oleh mereka yang hendak menghindari persekusi ini; sebuah tren migrasi berbahaya melintasi luasnya Laut Andaman yang telah terjadi sejak tahun 1960an. Krisis pun semakin parah khususnya sejak tahun 2012 lalu. Lebih dari 120,000 orang telah melarikan diri yang menandai salah satu krisis yang cukup besar di wilayah Asia Tenggara (Muhamad, 2012). Tidak hanya itu saja konflik sektarian berlatar belakang etnis dan agama ini sarat akan kontroversi historis. Tekanan yang diberikan terhadap masyarakat Rohingya oleh aparatur pemerintahannya sendiri ini terjadi bukan tanpa sebab. Menurut laporan dari Warzone Initiatives (2015), justifikasi yang diberikan oleh Pemerintah Myanmar danjuga sejarawan Myanmar mengatakan bahwa orang-orang Rohingya sejatinya merupakan kelompok etnis keturunan Muslim Bengali, dan bukan masyarakat 'asli' Myanmar. Terlebih lagi, Sohel (2017) juga memaparkan bahwa terdapat sirkulasi keyakinan di masyarakat Myamnar yang mengklaim bahwa di era kolonial Inggris, bangsa Rohingya bermigrasi dari wilayah Bengal selama kurun waktu antara tahun 1824-1948 dan diyakini terus berpindah bahkan hingga wilayah Myanmar telah resmi merdeka dari Inggris. Di sisi lain, terdapat pula sejumlah ahli di luar Myanmar yang meyakini bahwa bangsa Rohingya telah mendiami negara ini sejak abad ke-15. Bahkan, bukti serta prediksi terlama menyatakan bahwa hal tersebut telah berlangsung hingga dari abad ke-7. Diperkirakan sekarang ada sekitar 800,000-1,100,000 orang Rohingya yang bermukim di Myanmar. Sebanyak 80\% dari jumlah pemukim yang telah disebutkan dilaporkan tinggal di negara bagian Rakhine (Warzone Initiatives, 2015).

Apabila ditelusuri lebih lanjut, pola diskriminasi ini sejatinya telah tertanam dalam struktur pemerintahan Myanmar. Hal ini dapat 
dilihat dengan meninjau sejarah proses perundang-undangan dan legislasi di negara ini, utamanya regulasi yang mengatur mengenai kewarganegaraan. Sohel (2017) memaparkan bahwa sentimen ini bermula dari dikeluarkannya Undang-Undang Darurat Imigrasi pada tahun 1974 dan hukum mengenai kewarganegaraan yang dikeluarkan pada 1982. Keberadaan peraturan darurat imigrasi, membuat seluruh warga negara wajib membawa kartu identitas. Namun, dalam hal ini, warga Rohingya dianggap tidak memenuhi syarat untuk mendapatkan kartu identitas tersebut. Mereka hanya bisa mendapat akses terhadap kartu penduduk asing, dengan akses yang terbatas (Sohel, 2017). Dengan kata lain, perlakuan ini secara tidak langsung menunjukkan sikap Pemerintah Myanmar yang tidak mengakui eksistensi dari etnis Rohingya di negaranya. Kondisi ini semakin diperparah dan diafirmasi melalui peraturan baru yang dikeluarkan beberapa tahun kemudian, di tahun 1982. Warga Rohingya tidak dimasukkan ke dalam 135 etnis resmi yang diakui pemerintah. Keberadaan Rohingya dianggap sebagai imigran gelap dari Bangladesh dan, karena alasan itu, Rohingya tidak mendapatkan pengakuan (Warzone Initiatives, 2015).

Sebagai konsekuensinya, eksodus dalam skala masif pun terjadi. Mayoritas warga Rohingya lari ke perbatasan Bangladesh sebagai negara yang tidak hanya bertetangga, namun juga dianggap bersahabat karena kesamaan keyakinan. Proses eksodus besarbesaran ini menyebabkan Bangladesh kewalahan dan akhirnya memutuskan untuk menutup kamp pengungsian yang ditempati oleh warga Rohingya pada tahun 2005 silam (Muhamad, 2012). Situasi ini semakin memburuk lewat sebuah peristiwa yang meningkatkan tensi pada Mei 2012 lalu. Seorang wanita Budha di negara bagian Rakhine ditemukan tewas dan ditemukan tandatanda pemerkosaan. Tiga laki-laki Rohingya diduga kuat menjadi pelaku dari aksi sadis tersebut. Kerusuhan di antara kedua kubu tak terhindarkan, menyebabkan sekurang-kurangnya 200 korban jiwa (Sohel, 2017). Kekerasan dan kemunculan stigma berlandaskan sentimen anti-Muslim lantas terus berlanjut dan menyebar tidak hanya di negara bagian Rakhine, namun juga hampir ke seluruh Myanmar.

Indonesia, sebagai sesama negara ASEAN, dan tanpa menghilangkan rasa hormatnya pada Pemerintah Myanmar yang berdaulat, telah melakukan sejumlah inisiasi dan diplomasi yang berkaitan dengan konflik etnis yang bermula di negara bagian Rakhine ini. Presiden Joko Widodo (Jokowi) merespons krisis di Rohingya dengan mengirim Menteri Luar Negeri, Retno Marsudi sebagai perwakilan dari Pemerintah Indonesia pada 2017 lalu. Namun, hasil laporan 
dari Institute for Policy Analysis of Conflict (2018) menunjukkan bahwa Pemerintah Myanmar menolak permohonan dari Indonesia untuk memberikan bantuan kemanusiaan. Bahkan, laporan ini juga menuturkan bahwa administrasi Aung San Suu Kyi, yang selama ini dipuji oleh dunia karena perjuangannya terhadap demokrasi, terkesan menutup mata terhadap apa yang terjadi.

Melalui Langkah-langkah yang telah digagas, maka pembahasan mengenai kepentingan strategis Indonesia dalam isu ini menjadi perhatian tersendiri yang perlu didalami lebih lanjut. Menilik dari survei yang dilakukan oleh Institute for Policy Analysis of Conflict (2018), ditemukan bahwa simpati Indonesia pada Rohingya, tidak berlanjut dengan keinginan dan ketertarikan Indonesia untuk menampung bangsa Rohingya sebagai pengungsi. Lantas, hal ini seakan-akan memosisikan Indonesia secara naif hanya sebagai ‘jembatan kemanusiaan dan perdamaian' yang menjadi retorika dari Kementerian Luar Negeri Indonesia (Indrawati, 2018), tanpa adanya kepentingan riil. Indonesia juga bukan merupakan negara yang tidak menandatangani Konvensi Pengungsi PBB, yang mana menjelaskan mengapa jumlah pengungsi yang ada di Indonesia terhitung sebagai salah satu yang terendah di dunia (Zulfa, 2018). Langkah ini pun juga bisa dipahami, mengingat pemerintah Indonesia juga sebenarnya takut dengan adanya ancaman militan Arakan Rohingya Salvation Army (ARSA), militan separatis yang kerap kali bersembunyi di balik krisis Rohingya bersama-sama dengan pengungsi (Warzone Initiatives, 2015). Ketakutan ini bukan tanpa alasan, ARSA bisa saja melakukan kontak dengan militan separatis di Indonesia yang tidak menutup kemungkinan akan menimbulkan ketidakstabilan di wilayah Indonesia (Zulfa, 2018).

Artikel ini berusaha menjawab kepentingan nasional Indonesia dan cara Indonesia berdiplomasi atau diplomasi ala Indonesia sebagai salah satu mediator dalam konflik Rohingya. Selain itu, akan diadakan pula kajian lebih dalam mengenai relevansi kepentingan nasional serta cara berdiplomasi Indonesia dalam penyelesaian konflik Rohingya, utamanya dengan menyandingkan prinsip kebijakan politik luar negeri bebas-aktif yang senantiasa menjadi rujukan dalam melakukan perhelatan internasional. Untuk menelaah keseluruhan hal yang menjadi dasar penelitian, artikel ini akan dibagi atas lima bagian: pendahuluan, kerangka konseptual mengenai kepentingan nasional, diplomasi, serta teori realisme, kepentingan nasional Indonesia dalam penyelesaian konflik Rohingya, diplomasi ala Indonesia dalam penyelesaian konflik Rohingya, dan kesimpulan. 


\section{Memaknai Kepentingan Nasional, Diplomasi, dan Teori Realisme}

Dalam studi Hubungan Internasional, kepentingan nasional merupakan suatu tujuan dan ambisi negara dalam berbagai aspek di antaranya yang meliputi bidang ekonomi, militer, dan budaya (Bainus dan Rachman 2018). Kepentingan nasional memiliki keterkaitan yang cukup erat dengan aktualisasi kekuatan atau power yang dimiliki oleh suatu negara untuk mencapai tujuannya. Dalam pemaknaan klasik, penggunaan power dalam konteks pencapaian kepentingan nasional umumnya berkorelasi dengan orientasi kebijakan yang bersifat destruktif. Namun, seiring berjalannya waktu, penggunaan power yang bersifat destruktif atau bisa disebut sebagai hard power, mulai digantikan oleh kepentingan nasional yang bersifat kooperatif dan persuasif atau disebut juga sebagai soft power (Nye, 1990). Dalam implementasinya, pewujudan dari suatu kepentingan nasional harus diiringi pula dengan teknik dan cara berdiplomasi yang sesuai. Secara tradisional diplomasi memiliki arti sebuah seni bernegosiasi dengan negara lain. Namun seiring berkembangnya zaman para ahli meyakini bahwa diplomasi telah mengalami perubahan sifat. Konsep ini telah mencakup baik manajemen hubungan antar negara dalam artian tradisional, maupun juga dengan aktor non-negara lainnya (Effendi 2013).

Teori realisme yang merupakan salah satu kerangka teoretis yang cukup dominan dalam diskursus dan kajian studi Hubungan Internasional. Menurut Asrudin (2017) realisme, secara virtual, membentuk kerangka pemikiran seputar kebijakan luar negeri secara profesional. Dengan kata lain, realisme hendak memosisikan perilaku politik luar negeri dalam koridor realitas yang sejatinya penuh dengan intrik dan kepentingan yang bersifat praktis, atau lebih dikenal dengan sebutan realpolitik - berseberangan dengan kerangka idealisme politik maupun liberal institusionalisme (Dugis, 2018). Asrudin (2017) menambahkan bahwa pemikiran kaum realis sendiri berlandaskan pada agenda pencarian kekuatan dan dominasi yang mana berasal dari sifat dasar manusia. Morgenthau meyakini bahwa negara, sama seperti manusia: selalu memiliki keinginan untuk mendominasi yang lainnya dan akhirnya menimbulkan konflik dan peperangan. Berakhirnya era kolonialisme dan Perang Dingin, serta peristiwa 9/11 menjadi turning-point tersendiri bagi proliferasi aktor dan diskursus hubungan internasional; demikian adanya pergeseran pemaknaan kepentingan nasional, termasuk dalam koridor realisme, yang kini beriringan dengan penggunaan soft power dalam penerapannya (Bainus dan Rachman 2018; Dugis, 2018). Dalam mengamati kepentingan nasional Indonesia 
dalam penyelesaian krisis Rohingya, lantas diperlukan penggunaan teori realisme. Artikel ini lebih lanjut akan menggunakan kerangka teoretis ini untuk mengidentifikasi kepentingan strategis yang dikejar oleh Indonesia.

\section{Kepentingan Nasional Indonesia dalam Penyelesaian Konflik Rohingya}

Sepertitelah dijelaskan sebelumnya, hasillaporan WarzoneInitiatives (2015) memperkirakan ada lebih dari 120,000 orang Rohingya yang meninggalkan Myanmar dan menjadi pengungsi. Ada tiga negara ASEAN yang menjadi tujuan orang-orang Rohingya yang melarikan diri, di antaranya: Indonesia, Malaysia, dan Thailand. Ketiga negara sepakat untuk menampung keberadaan pengungsi Rohingya untuk periode selama satu tahun. Namun, ketika negara tersebut bukanlah tujuan akhir, melainkan sebagai persinggahan. Umumnya, para pengungsi tersebut menetapkan Australia sebagai tujuan akhir karena dipercaya akan adanya jaminan dan perlindungan politik yang akan diberikan oleh negeri Kanguru (Jati 2018).

Dalam melakukan interaksi internasional, setiap negara yang terlibat dalam perhelatan initidak dapat dipungkiri memiliki kepentingannya masing-masing. Tidak jarang pula ditemukan bahwa kepentingankepentingan ini acapkali berbenturan satu sama lainnya (Sudarsono et al., 2018). Indonesia, dengan posisinya sebagai negara berdaulat dalam sistem internasional, tentunya juga memiliki kepentingan tersendiri, utamanya dalam konteks penyelesaian konflik Rohingya yang terbukti dengan keterlibatannya yang cukup tinggi dalam prosesnya. Melihat berbagai fakta yang ada, tidak dipungkiri bahwa kehadiran pengungsi Rohingya cukup memberatkan bagi negara berkembang seperti Indonesia. Seperti dikutip dari tulisan Noor Aspasia (2015) yang dimuat dalam CNN Indonesia, Wakil Presiden Indonesia saat itu, Jusuf Kalla (JK), menyatakan bahwa penampungan pengungsi Rohingya di Indonesia dilakukan dengan alokasi dana sebesar Rp2,3 miliar dari anggaran Kementerian Sosial. Dana ini sendiri hanya dapat digunakan untuk menanggung kurang dari 2000 orang pengungsi, jumlah yang sangat jauh dari perkiraan jumlah pengungsi yang datang. Namun, JK juga menuturkan bahwa bantuan dari pihak asing telah datang ke Indonesia. Singapura, misalnya, menyumbang sekitar Rp2,6 miliar bagi penampungan pengungsi. Terlepas dari bantuan yang hadir, biaya operasional yang perlu dikeluarkan pemerintah Indonesia untung menampung pengungsi Rohingya tidak sedikit. 
Tidak hanya mengenai biaya, kenyataan bahwa Indonesia bukan merupakan keinginan utama atau tujuan akhir bagi pengungsi Rohingya juga dinilai memperparah keadaan. Pada 2017 lalu, simpati dunia pada warga Rohingya terlihat cukup meningkat. Namun, di tengah-tengah meluasnya sentimen kepedulian ini, seorang pengungsi di Aceh menuturkan sebuah pernyataan buruk tentang Indonesia dalam sebuah laporan langsung di televisi lokal. Pengungsi bernama Saleem ini mengatakan:

"Kami (pengungsi Rohingya) senang, karena warga Indonesia bersedia menerima dan menolong kami. Tapi, nilai tukar Rupiah terbilang kecil. Sebab itulah kami berharap bisa pergi ke Amerika Serikat, supaya kehidupan kami lebih baik. Di sana nilai tukar Dollar terbilang tinggi” (Gunadha 2017).

Pernyataan ini tentunya dikecam oleh warga Indonesia. Banyak di antara mereka yang mengekspresikannya dengan ungkapan bahwa warga Rohingya yang mengungsi di Indonesia tidak mendudukkan diri pada tempatnya (Gunadha, 2017). Namun, perlu diketahui bahwa sentimen negatif yang dirasakan oleh sebagian masyarakat Indonesia ini tidak serta merta membuat pemerintah Indonesia melakukan tindakan deportasi atau pemulangan paksa pengungsi Rohingya ke negara asal.

Bila dipandang dalam menurut teori realisme, peristiwa-peristiwa di atas bukan menunjukkan keberadaan Indonesia sebagai sebuah negara yang menghindari adanya sikap-sikap ofensif maupun provokatif. Perlu diingat bahwa mayoritas penduduk Indonesia beragama Muslim. Komunitas Rohingya yang menjadi pengungsi di Indonesia pun mayoritas menganut agama Islam. Dalam melakukan penindakan terhadap komunitas Rohingya yang mengeluarkan pernyataan seperti di atas, pemerintah Indonesia bermain cukup hati-hati. Tindakan deportasi sepihak bukanlah perbuatan yang tepat, mengingat komentar di atas bisa saja merupakan bentuk ketidaksengajaan; membuat opsi ini justru berpotensi memunculkan tudingan tindak pelanggaran HAM (Zulfa, 2018). Dengan kata lain, tindakan ini dinilai dapat berbalik memberi kecaman ke arah pemerintah. Hal ini misalnya dapat dimanfaatkan oleh organisasiorganisasi tertentu yang dapat dimanfaatkan oleh pihak oposisi, sehingga mengancam status quo dan ketidakstabilan di dalam negara. Tindakan deportasi mungkin dapat dilakukan apabila perbuatan yang dilakukan mungkin sudah menyentuh kejahatan kriminal yang mana menjadi justifikasi yang dibenarkan. 
Pemerintah Indonesia lantas membutuhkan tindakan cepat-tanggap dalam menyelesaikan permasalahan yang cukup pelik ini dengan mempertimbangkan pula keadaan di sisi domestik. Salah satu permasalahan keamanan lain yang menjadi pertimbangan adalah ketakutan akan masuknya milisi dari ARSA ke wilayah Indonesia. Adanya potensi masuknya milisi ARSA di wilayah Indonesia tentunya sangat berbahaya bagi stabilitas. Selain bisa memancing bangkitnya kelompok separatisme yang tersebar di luas, milisi ARSA juga bisa saja melakukan gangguan keamanan yang dapat mengancam warga Indonesia. Tidak menutup kemungkinan akan timbul aksi teror untuk menarik perhatian dunia internasional (Zulfa, 2018).

Selain itu, sikap yang berhati-hati dan praktis ini didasarkan pada konsiderasi status quo dari pemangku kekuasaan yang ada. Pemerintahan Indonesia, utamanya di era Presiden Joko Widodo (Jokowi), sering kali dicap dan diguncang oleh isu sebagai rezim yang anti terhadap keberadaan Islam. Tekanan koalisi Islam disinyalir berusaha mengguncang pemerintahan Jokowi menjelang pemilihan presiden yang terjadi di awal tahun 2019 silam. Hal ini berhasil diredam dengan meningkatkan jumlah bantuan pada kamp pengungsi yang berada di Bangladesh. Meski terlihat seakan-akan sejalan dengan retorika politik luar negeri Indonesia yang bebasaktif, kebijakan ini memiliki hubungan dengan agenda pragmatis untuk menjaga stabilitas dalam negeri. Kontradiksi dengan kebijakan yang telah disebutkan sebelumnya ditunjukkan dengan belum diambilnya tindakan ataupun komitmen untuk menampung lebih lagi pengungsi Rohingya di wilayah Indonesia (Institute for Policy Analysis of Conflict, 2018).

Perlu diakui bahwa negara-negara Muslim lainnya seperti Bangladesh dan Arab Saudi juga melakukan tindakan deportasi terhadap komunitas Rohingya. Tulisan Ullah (2019) menyebutkan bahwa sejumlah pengungsi Rohingya memasuki Saudi dengan menggunakan visa umrah. Ketika didapati bahwa ternyata mereka sudah tinggal melebihi batas maksimum, maka tindakan deportasi pun dilakukan dengan dikembalikannya mereka ke Bangladesh. Ironisnya, otoritas Bangladesh akan mengirim mereka ke kamp pengungsi ataupun memenjarakan mereka setelah dipulangkan. Tentunya hal ini menimbulkan kecaman dari dunia internasional. Tindakan represif yang dilakukan oleh Arab Saudi dan Bangladesh tersebut bukanlah menjadi suatu hal yang baru, utamanya mengingat dinamika politik yang terjadi di kedua negara tersebut. Menurut indeks demokrasi yang dikeluarkan oleh The Economist (2018), Bangladesh menduduki peringkat ke-88, sedangkan Arab Saudi ke-165; jauh di bawah Indonesia (65). Lantas, perilaku 
represif semacam itu sudah menjadi hal yang biasa di negara yang notabenenya kurang demokratis.

Sebagai negara demokrasi bukan berarti kita harus diam. Pemerintah Indonesia tentunya harus memiliki pertimbangan yang matang seputar isu ini. Di satu sisi tidak dapat membiarkan pengungsi Rohingya terus berada di Indonesia, mengingat secara realistis biaya yang dikeluarkan juga tidak sedikit dan bahkan membebankan (Gunadha, 2017). Namun, di sisi lain, pemerintah juga tidak menginginkan adanya gejolak di dalam negeri yang timbul sebagai respons terhadap tindakan-tindakan negatif warga Rohingya yang berada di Indonesia (Zulfa, 2018). Sehingga, dibutuhkan caracara yang matang dan tepat sasaran dalam menyelesaikan isu ini. Demokrasi tidak boleh kita tekan namun tindakan tegas juga diperlukan.

Karena itu, tentunya pemerintah Indonesia bisa melakukan caracara diplomatis untuk menyelesaikan permasalahan kompleks yang dihadapi dalam penyelesaian konflik Rohingya. Kepentingan nasional Indonesia baik di dalam maupun luar negeri harus tetap menjadi prioritas. Untuk itu diperlukan teknik diplomasi yang sesuai dengan keadaan (Sudarsono et al., 2018). Teknik diplomasi ini diperlukan untuk membuka dialog dengan pemerintah Myanmar seputar penyelesaian konflik Rohingya beserta dampaknya ke Indonesia, yaitu kehadiran pengungsi. Selain itu diplomasi juga diperlukan untuk menjangkau negara-negara yang sekiranya dapat menjadi tempat penampungan sementara ataupun pemberi bantuan bagi para pengungsi Rohingya yang sudah berada di Indonesia. Maka, cara Indonesia berdiplomasi atau diplomasi ala Indonesia akan sangat penting untuk menentukan arah penyelesaian masalah ke depannya (Zulfa, 2018).

\section{Diplomasi ala Indonesia dalam Penyelesaian Konflik Rohingya}

Indonesia telah menerapkan prinsip kebijakan luar negeri bebas-aktif sejak awal kemerdekaan. Pada era Soekarno, hal ini dimanifestasikan dalam wacana "mendayung di antara dua karang" yang menggambarkan situasi pertentangan sengit dan perebutan pengaruh antara dua ideologi besar di masa Perang Dingin. Sementara di era Susilo Bambang Yudhoyono (SBY) digambarkan sebagai "Navigating in the Turbulance Ocean" yang kemudian berkembang menjadi "Thousand Friends Zero Enemy" di periode kedua masa jabatannya yang menekankan pentingnya diplomasi yang kooperatif (Indrawati 2018). Ilustrasi-ilustrasi tersebut 
lantas menekankan bahwa politik bebas aktif masih tetap relevan dan senantiasa beradaptasi mengikuti perkembangan zaman. Refleksi dari pemaknaan awal masa Perang Dingin, kata "bebas" di sini mengacu pada posisi Indonesia yang tidak memihak ke kubu mana pun dan "bebas" untuk melakukan hubungan dengan keduanya secara pragmatis dengan berbasis pada kepentingan nasional. Sementara kata "aktif" menegaskan peranan Indonesia yang senantiasa aktif dalam interaksi internasional dan menjaga perdamaian dunia (Effendi, 2013), seperti menengahi suatu konflik.

Keberadaan prinsip politik bebas-aktif yang masih relevan lantas menunjukkan pola Tindakan yang dilakukan oleh Indonesia dalam upaya diplomasi terkait konflik Rohingya dengan pihak-pihak terkait. Bebas-aktif memungkinkan Indonesia untuk mencapai kepentingan nasional lewat upaya diplomasi tanpa memihak kepada kubu tertentu serta tetap mengupayakan perdamaian dunia sebagai kepentingan nasional, seperti halnya yang tertuang dalam Undang-undang Dasar (Indrawati, 2018). Di dalam upaya penyelesaian konflik Rohingya, Indonesia telah melakukan berbagai inisiasi-inisiasi proaktif, seperti pemberian bantuan yang dilakukan Indonesia sejak konflik pecah di Myanmar sejak 2012 lalu. Indonesia juga mengupayakan pendirian 6 sekolah yang terbagi atas dua tahap: pembangunan tahap pertama pada Desember 2014 menghasilkan sebanyak 4 sekolah; dan tahap kedua pada 21 Januari 2017 sebanyak 2 sekolah. Tidak hanya itu, inisiasi di bidang kesehatan juga tengah diupayakan, yakni dengan pendirian Indonesian Health Centre di negara bagian Rakhine (Zulfa 2018).

Upaya diplomasi secara langsung juga telah dilakukan oleh Presiden Jokowi dengan menghampiri Aung San Suu Kyi di tengah perhelatan KTT ASEAN medio pada 28 April 2017 lalu di Manila, Filipina. Tatap muka diplomatis ini pun dilakukan dengan intensif. Empat bulan kemudian, tepatnya pada 4 September 2017, Indonesia, diwakili oleh Menteri Luar Negeri Retno Marsudi menyampaikan proposal bantuan kemanusiaan dari Indonesia untuk pengungsi dan korban konflik Rohingya kepada Aung San Suu Kyi (Zulfa 2018). Berdasarkan tindakan diplomasi yang dilakukan Indonesia tersebut, dapat diketahui bahwa kebijakan politik luar negeri bebas aktif telah disesuaikan dengan perkembangan zaman dan diskursus internasional, tepatnya dengan menerapkan persuasi dan diplomasi berbasis soft power.

Apabila dikaji dengan pendekatan teoretis realisme, negara merupakan aktor yang selalu berupaya untuk memenuhi kepentingan nasionalnya. Namun, di dalam upayanya tersebut, 
cara-cara yang ditempuh pun juga pragmatis (Dugis, 2018). Dalam konteks Rohingya hard power atau yang bisa digambarkan sebagai upaya angkat senjata destruktif bukanlah jalan yang relevan untuk ditempuh dalam mewujudkan kepentingan nasional Indonesia dalam mencapai perdamaian dunia dan stabilitas domestik. Penggunaan upaya soft power - yang ditunjukkan dengan adanya diplomasi dan inisiasi-inisiasi proaktif lainnya - tidak hanya menjamin keberadaan dunia yang aman, namun juga dapat meningkatkan citra suatu negara di mata dunia. Indonesia juga tidak serta merta mengusir penduduk Rohingya dari wilayahnya begitu saja. Diplomasi kembali ditekankan sebagai sarana menuju pemecahan.

\section{Kesimpulan}

Berdasarkan dari apa yang telah dijabarkan, lantas dapat diketahui bahwa kepentingan nasional Indonesia di dalam upaya penyelesaian konflik Rohingya tetap menjadi prioritas. Biaya penampungan yang besar, adanya politisasi bermotif identitas, hingga ancaman separatisme dapat mengancam kepentingan nasional Indonesia sebagai sebuah bangsa. Selain itu, Indonesia juga memiliki kepentingan ideasional untuk menjaga secara aktif perdamaian dunia. Kedua hal tersebut lantas diakomodasi melalui prinsipprinsip diplomasi ala Indonesia: kebijakan luar negeri bebas-aktif yang telah berperan krusial sebagai norma utama dalam interaksi internasional semenjak negara ini merdeka

Atas dasari prinsip-prinsip ini, diplomasi pun dilakukan melalui cara-cara persuasif yang sesuai dengan keadaan, seperti: pemberian bantuan langsung, pengajuan proposal kemanusiaan, serta tatapmuka dan dialog secara langsung baik oleh presiden maupun perwakilannya. Politik bebas aktif menjamin keberadaan Indonesia untuk membantu komunitas Rohingya tanpa harus bersikap ofensif terhadap pemerintah Myanmar dan tetap aktif untuk menyebarkan perdamaian ke dunia. Selain itu, lewat bentuk bantuan pembangunan yang ada serta dialog dengan pemerintah Myanmar, kepentingan nasional Indonesia khususnya di bidang ekonomi, pertahanan, dan keamanan dapat terjaga dengan adanya keinginan dari dalam komunitas Rohingya untuk kembali ke tempat mereka berasal di negara bagian Rakhine.

Karena itu dapat kita simpulkan bahwa kepentingan nasional Indonesia dalam upaya penyelesaian konflik Rohingya dapat tercapai lewat upaya diplomasi yang berdasarkan pada politik bebas aktif yang mengandung nilai-nilai pragmatisme. Agar upaya diplomasi dapat berjalan dengan lancar, Indonesia seharusnya terus 
mempertahankan penggunaan kebijakan bebas-aktif yang selalu adaptif dengan keadaan yang ada. seperti halnya yang terjadi dalam konteks upaya penyelesaian konflik Rohingya, kepentingan nasional Indonesia dapat terjamin dengan baik dan perhelatan internasional pun dapat dijalankan dengan saksama. 


\section{Daftar Pustaka}

\section{Buku dan Bab dalam Buku}

Dugis, Vinsensio, 2018. "Teori dan Teori Hubungan Internasional." dalam Vinsensio dugis (ed.) Teori Hubungan Internasional (Perspektif-Perspektif Klasik). Surabaya: Airlangga University Press.

\section{Artikel Jurnal}

Asrudin, A. 2017. "Thomas Kuhn dan Teori Hubungan Internasional: Realisme sebagai Paradigma”, Global South Review, 1(2):107.

Bainus, A., \& Rachman, J. B. 2018. "Editorial: Kepentingan Nasional dalam Hubungan Internasional”, Intermestic: Journal of International Studies, 2(2):109.

Effendi, T. D. 2013. "Diplomasi Publik Sebagai Pendukung Hubungan Indonesia-Malaysia", Jurnal Ilmiah Hubungan Internasional (Parahyangan Center for International Studies), 9(1).

Indrawati, A. N. (2018). "Penerapan prinsip politik luar negeri indonesia melalui diplomasi maritim", Jurnal Ilmiah Hubungan Internasional (Verity), 10(20):14-26.

Jati, I. (2018). "Comparative Study of the Roles of ASEAN and the Organization of Islamic Cooperation in Responding to the Rohingya Crisis”. The Indonesian Journal of Southeast Asian Studies (IKAT), 1(1): 17.

Muhamad, Victor Simela. 2012. "Tragedi Kemanusiaan Rohingya". Info Singkat Hubungan Internasional, 4(15).

Nye, Joseph S., 1990. “Soft Power”. Foreign Policy, 80: 153-171.

Sohel, Muhammad Salman. 2017. "The Rohingya Crisis in Myanmar: Origin and Emergence". Saudi Journal of Humanities and Social Sciences. 2(11).

Sudarsono, B. P., Mahroza, J., \& D.W., S. (2018). “Indonesia Defense Diplomacy in Achieving National Interest". Jurnal Pertahanan \& Bela Negara, 8(3): 83-102. 
Zulfa, R. (2018). Diplomasi Indonesia dalam Penanganan Konflik Rohingya 2013-2017. JOM FISIP, 5(2): 1-11.

\section{Laporan dan Publikasi Resmi}

Institute for Policy Analysis of Conflict. 2018. Indonesia and the rohingya crisis. No. 46. 2018

The Economist. 2018. Democracy Index 2018: Me too? Political participation, protest and democracy, 2018

\section{Publikasi Daring}

Gunadha, R. 2017. "Dinilai Hina Indonesia, Video Pengungsi Rohingya Ini Bikin Kesal” [Daring] Suara.com. Tersedia dalam: https://www.suara.com/news/2017/09/18/134341/ dinilai-hina-indonesia-video-pengungsi-rohingya-ini-bikinkesal [Diakses 8 April 2020].

Noor Aspasia, S. 2015. "Bantu Pengungsi Rohingya, Pemerintah Rogoh Kocek Rp2,3 Miliar" [Daring] CNN Indonesia. Tersedia dalam: https://www.cnnindonesia.com/ internasional/20150525190121-106-55602/bantu-pengungsirohingya-pemerintah-rogoh-kocek-rp23-miliar [Diakses 8 April 2020].

Ullah, A. 2019. "Saudi Arabia deporting Rohingya despite UN calls to give them refuge" [Daring] Middle East Eye. Tersedia dalam: https://www.middleeasteye.net/news/saudi-arabiadeporting-rohingya-despite-un-calls-give-them-refuge [Diakses 8 April 2020].

Warzone Initiative, 2015. "Rohingya Briefing Report" [Daring]. Tersedia dalam: https://www.warzone.cc/2015/10/rohingyabriefing-report/ [Diakses 8 April 2020]. 